\title{
Creative Thinking Skills Enhancement Using Mind Mapping
}

\author{
Mauren Gita Miranti, Biyan Yesi Wilujeng \\ Department of Home Economics, Universitas Negeri Surabaya \\ Surabaya, Indonesia \\ $\underline{\text { maurenmiranti@unesa.ac.id }}$
}

\begin{abstract}
Creative thinking skill is one of the needed skills in this era of globalization. It can be used to solve the problems and develop the idea. Creative thinking skill is not developed by itself, but it takes the stimulation and encouragement. The aim of this study is to determine the improvement of students' creative thinking skill. The method used is quasi experiment, with design of non equivalent control group design. The results showed that mind mapping method can significantly improve students' creative thinking ability.
\end{abstract}

Keywords----creative thinking, skill, mind mapping, learning.

\section{INTRODUCTION}

There are various learning problems that often occurred among students. It includes the ability (1) to concentrate; (2) to understand what is being learned; (3) to remember what is being said; (4) to receive much more things in the brain [1]. Only $5 \%$ of Indonesian students can work on a high category and advanced questions (requires reasoning), while $71 \%$ of Korean students are able to work on that questions. In other perspectives, $78 \%$ of Indonesian students can only work on a low category questions (requires only knowing or memorizing), so it is necessary to develop a curriculum that demands the reinforcement of reasoning. In addition, other problems that occur are (1) in learning, creative thinking skill have not been handled properly [2], (2) in the learning process, it still relies how to understand concepts, principles, and theories that it is not becoming as means to empower students' creative thinking skill, (3) lecturers do not know the right way to improve students' creativity in classroom learning process [3] and (4) the learning approach used to develop creative thinking skill is too difficult for students with limited knowledge and creative thinking skill [4].

Nowadays, the development of science demands the students in order able to compete by developing skills and knowledge. Skills is considered importantly to be developed by students as high level thinking skills [5]. High level thinking skills are the ability to utilize a new information or prior knowledge and manipulate it in order to get the possible answers in a new conditions [6]. Students are able to think in a high level term when they are facing the problems or the questions, so that they are eventually able to generate ideas to solve those problems [7]. There are the three thinking skills that must be possessed. They are creative thinking skills and innovating; critical thinking and problem solving, as well as metacognition thinking [8].

One of the most important thinking skills to develop in education is the creative thinking skill [9][10][11]. Creative thinking is a cognitive activity to find solutions in solving the problem [12][13]. Creative thinking is an original. It functions in reflecting the way of thinking and producing a complex product. Creative thinking is to synthesize ideas, generate new ideas, and determine the effectiveness of existing ideas [14]. As noted by Jarvis [19], map-making improves the usability of information and also compliments on what the brain can do imperfectly.

To improve the lack in student learning, it can be done by using one of the learning strategies such as mind mapping. Mind mapping is a technical graphics that allows us to explore all of our brain's ability to think and learn [1]. Mind mapping activity is originally described by hand, but nowadays, due to its development of technology, mind mapping activities can be done by applying mind mapping software. Mind mapping software can support constructivism based on learning design. It provides the opportunity for students to practice and construct their own building science that needs to be applied. To solve the problem, this study aimed to improve on creative thinking by using draw mind mapping.

\section{METHOD}

This study used a quasi experiment which used quantitative descriptive method. The samples are 61 bachelor of culinary education student in the third year, which has two classes. They are class A, as experiment class and class B as control class. The research group used e-draw mind map which had been designed by Wilujeng [15] that was used as a learning media in this present study.

The instrument used a set of questions on the ability of creative thinking to find out how much improvement of students' critical thinking skills before and after learning activities. The data used for the hypothesis test should be normally distributed and homogeneous. Therefore, the requirements analysis test was performed, including normality and homogeneity test, followed by hypothesis test of t-test. Description analysis is used for a number of data collected, to obtain a description of the ability to think creatively. 


\section{RESULTS}

Buzan's mind mapping [16] is the easiest way to get information into the brain and to retrieve information from it. This is the most creative and effective way of recording. It can be said that mind mapping is really mapped the minds of the people who made it. The learning steps using mind map method are presented above:

\section{Lecturer}

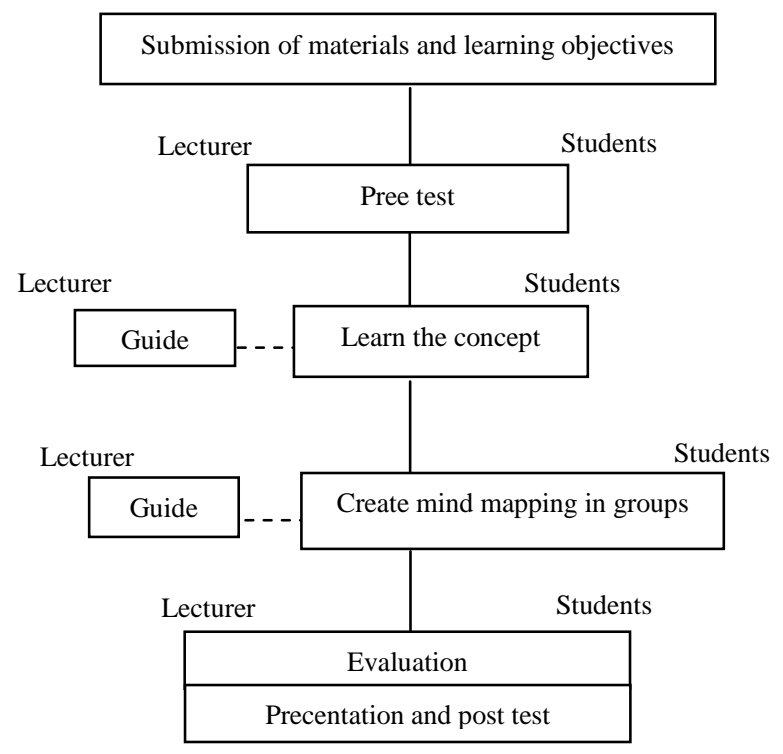

Fig 1. Learning Process Using Mind Mapping Method

Learning method using Mind Mapping is designed to develop students' knowledge with creative activities composing the main idea of a concept into the mind map. So it is easy to understand by the students. Mind mapping allows students to explore the association among concepts and it is also free-forming [17]. In addition, it also has the personal relationship of the person to the coursework [18]. It can be occurred through an interaction that information is stored by the students' permanent memory, so they are now able to mirror the key concepts with personal memories or events [17].

As the student works through the mapping process, they begin to relate to personal ideas and lock that principle or idea into a student's long-term memory [19]. Therefore, there is the relation between information given to the students and the linking material. Here are steps to make mind mapping: 1) determine and write the main topic in the center of the paper; 2) determine keywords in each sub theme; 3) look for illustrations, symbols, or codes for sub themes; 4) create a sub-theme branch, the created branch must be related to the main topic in the middle of the paper. The main branch line is thicker and thinner as it moves away from the main branch; 5) use colors on the mind map at least three colors, as it is needed; 6) develop a mind map that fits to their own style or creativity. Design problems are highly variable and complex in requiring a higher level of thinking. When solving the system of design problems on the students, it must meet the needed desired within realistic economic, environmental, social, political, ethical, health and safety manufacturability, and sustainability[20]. Here are some examples of mind mapping made by the students:
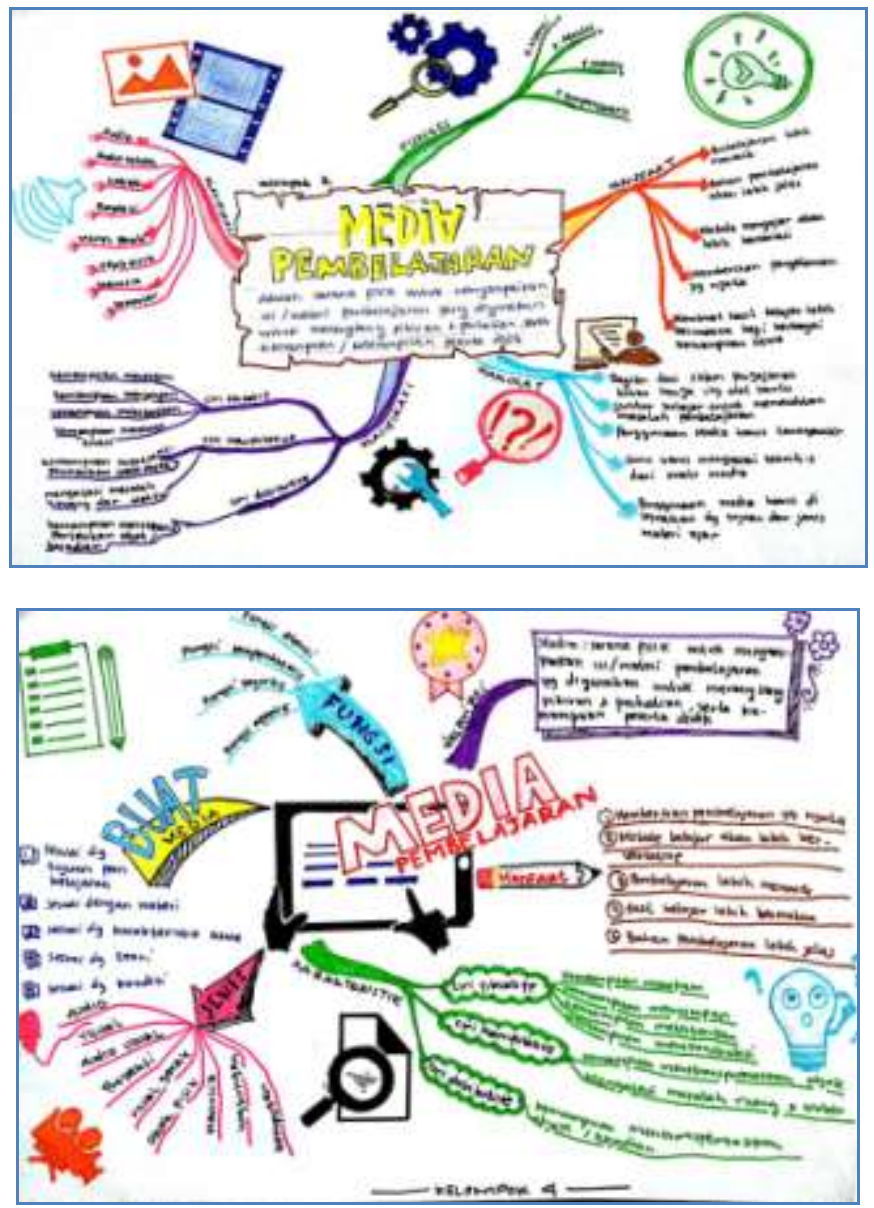

Fig 2. Mind Mapping about Concept of Media Pembelajaran Made by Student

Table 1 shows both pre test and post test results of cognitive students in the basic conceptual materials of instructional media. The result of pre test of creative thinking skill of experiment class has an average value of 40.53 and control class is 40.85 . While the results of post test of experiment class has an average value of 76.24 and control class of 71.28 .

TABLE I. RESULTS OF STUDENTS' CREATIVE THINKING ABILITY (BASIC CONCEPTUAL MATERIAL OF INSTRUCTIONAL MEDIA)

\begin{tabular}{|l|c|c|c|c|c|}
\hline & $\mathbf{n}$ & $\begin{array}{c}\text { Control } \\
\text { Class } \\
(\boldsymbol{x})\end{array}$ & $\mathbf{s}$ & $\begin{array}{c}\text { Experiment } \\
\text { Class } \\
(\boldsymbol{x})\end{array}$ & $\mathbf{s}$ \\
\hline Pre test & 29 & 40.85 & 1.206 & 40.53 & 1.204 \\
\hline Post test & 32 & 71.28 & 1.630 & 76.24 & 1.636 \\
\hline Gain & & 0.514 & & 0.60 & \multicolumn{3}{|c|}{ Sources: SPSS 19 (2017) }
\end{tabular}

From the pretest data, the initial ability of students' creative thinking in the basic concept materials of instructional media has an average value of 40.85> 40.53; standard deviation $1.204<1.206$. This indicates that students' 
initial ability in creative thinking skills of experimental class and control class does not have different significantly and tends to be the same. The comparison of final ability of post test of students has an average of $71.28<76.24$; standard deviation 1.636> 1.630. It means that the in the post test/final has the ability to think creatively. In this case, the student of experimental class is better than student in control class. The data are processed using SPSS 19 with Kolmogorov -smirnov test and 5\% significance level. After the normality test has performed, the distribution of data of creative thinking skill is found that the data is normally distributed. The data obtained from normality test of creative thinking skill uses SPSS program, a significant value for experiment class and control class is 0.084 and 0.125 , is bigger than 0.05 . The data is said to be normal distribution. Homogeneity test results obtained significant variables 0.249 is bigger than 0.05 . The data of creative thinking skill experimental class and control class are homogeneous.

Based on the descriptive result of students' creative thinking skill, the average value of the experimental group is higher than the control group's average score. This is due to its different treatment in which the experimental group. It is used the mind map method, the activities of students in the learning process as actively and creatively express the ideas in the form of mind maps. So that, students are easier to remember and present in front of the class. While the student in control group were less active in the learning process. Here, the lecturer is role as the informer.

From the results of the data, it is known the ability of students' creative thinking in the basic concept of instructional media. The use of mind mapping method is better than the conventional way. It can be assumed that the learning method applied in the class is quite influential on students' creative thinking skill. This is due to learning with mind mapping method give much beneficial to them. It require students to generate many ideas regarding to the concept given by lecturers and poured into a mind map, train students to have to be more freedom in giving all their ideas about a concept creatively, as well as the development of any ideas eliciting elaboration capabilities that build something from other ideas. In addition, the students present a unique and colourful form of mind map, train them to understand the mind map that created by themselves and practice to express their ideas smoothly in front of the class.

Based on the data, it can be seen that the average change in pre test and post test both the experimental class and control class. It shows the change in value in the experiment class is better than in the control class. It means that the ability of students to think creatively using the mind mapping method is better than the usual way. The result of the calculation on the similarity of two averages in the paired data is presented. The improvement of students' creative thinking skill using mind mapping method is better than the usual way. Overall, based on the results of the process, it can be concluded that the improvement of students' creative thinking skill in the material Basic Concepts of Instructional Media using mind mapping method is better than the usual way. The differences on the ability of students' creative thinking are not generated from a coincidence, but it is caused by the following matters: (1) previous students already know the various instructional media and at least know the function of media in learning, so it makes the students to be easier in the process of constructing their initial ability in mind mapping; and (2) the use of innovative method of learning, mind mapping method, has a big influence in improving students' creative thinking skill. It is because learning is more fun and independent. It will allow the students' motivation to learn, especially in theoretical learning.

In addition, learning using mind mapping method provides a good opportunity to develop students to be more creative and imaginative. It also invites students to create visual and graphic subject matter that can ultimately help record, reinforce and recall the information learned. Concept of maps has their roots in term of cognitive psychology and they attempt to illustrate a visual representation of the dynamic schemes of understanding within the human mind [21]. Mind Mapping is technique that develops a visual learning style. It integrates and develops the potential working of the brain within a person. Within the involvement of the two hemispheres of the brain, it will allow someone to organize and remember all forms of information, both in writing and verbally. The creative, effective and literally of mapping the minds, is also a route map that facilitates memory and makes it possible to construct facts and thoughts, thereby the natural workings of the brain involved from the beginning. This means that remembering information will be easier and more reliable than using traditional note-taking techniques. From the analysis, the use of mind mapping method is better and effective for students' creative thinking skill in the learning process.

This is in line with study conducted by Priantini [22] that there are significant differences between students who learn using Mind Mapping and students who learn in conventional way. Students who learn using Mind Mapping method have a better creative thinking than those who learn using conventional method. In addtion[23] find out on the difference of DI instruction model (direct instruction) through mind mapping method and conventional method toward creative thinking ability and physics learning achievement in junior high school students of Wahid Hasyim Malang.

Mind mapping method is one of solutions to improve the creative thinking skill. By making the mind mapping or concept map in learning as well as providing opportunities for students, it makes them to be creative and concise. So that it is in accordance with the students need. Nevertheless, the research using mind mapping techniques can help the lecturers' understanding how students mentally represent the design problems. It can also help the lecturers to use scaffolding techniques in an appropriate way in order to guide students in solving the complex designing problems [24].

\section{CONCLUSION}

From data analysis and discussion, it can be concluded that the use of mind mapping can develop students' creative thinking skill. The students have the opportunity to innovate 
themselves in organizing the learning materials using keywords or images, page and updating knowledge acquisition. The achievement of students' creative thinking skill is better when using mind mapping, rather better than the conventional way. Students' achievement on using mind mapping and conventional approach, are categorized in the average level.

\section{ACKNOWLEDGMENT}

We would also like to show our gratitude to Prof. Lutfiah Nurlela, M. Pd., for sharing their pearls of wisdom with us and we thank for our students "S1 Tata Boga 2015". Deeply indebted for our wonderful mom for her warn support, inspiration and thoughtful guidance.

\section{REFERENCES}

[1] Windura, Susanto. (2008). Mind Map Langkah Demi Langkah. Jakarta: Elex Media Komputindo.

[2] Rofi'uddin, A. (2000). Model Pendidikan Berpikir Kritis Kreatif untuk Siswa Sekolah Dasar. Majalah Bahasa dan Seni 1 (28): 72-94

[3] Laius, A., \& Rannikmae, M. (2014). Longitudinal Teacher Training Impact on Students' Attributes of Scientific Literacy. International Journal of Humanities and Social Science, 4(6): 63-72.

[4] Cheng, V.M.Y. (2010). Teaching Creative Thinking In Regular Science Lessons: Potentials And Obstacles Of Three Different approaches in an Asian context. Asia-Pacific Forum on Science Learning and Teaching, 11(1), Article 17, p.1.

[5] Kotzer, S \& Elran, Y. (2012). Learning and Teaching With MoodleBased E-Learning Environments, Combining Learning Skills And Content In The Fields Of Math and Science \& Technology. 1 st Rsearch Conference Proceedings Heraklion, Crete-Greece September.

[6] Heong, Y. M., Othman, W. D., Md Yunos, J., Kiong, T. T., Hassan, R. \& Mohamad, M. M. (2011). The Level Of Marzano Higher Order Thinking Skills Among Technical Education Students. International Journal of Social and Humanity, 1(2): 121-125.

[7] Gulistan, A.M.S., Siraj, S., Nordin, A.B. \& Amedy, S.O. (2015) Teaching Strategies For Promoting Higher Order Thinking Skills: A Case Of Secondary Science Teachers. Malaysian Online Journal Of Educational Management (MOJEM).: 3(4):16-30.

[8] Griffith P., McGaw, B., \& Care, E. (Eds.). (2012). Assessment and teaching of 21st skills. New York: Springer Publishing Company.

[9] Chan. D. W. (2007). Creative Teaching in Hong Kong Schools: Constraints and Challenges. Hong Kong Educational Research Journal, 22(1): 1-11
[10] Pasific pilicy research center. (2010). 21st Century Skills for Students and Teachers. Honolulu: Kamehameha Schools, Research \& Evaluation Division.

[11] Turkmen. (2015). Creative Thinking Skills Analyzes Of Vocational High School Students Journal Of Educational And Instructional Studes In The World, 5(1): 74-84.

[12] Adams. K. (2005). The Sources Of Innovation On Creativity. A Paper Commsioned by The National Center On Education And The Economy For New Commision on the Skills Of The American Workforce. National Center On Education and The Economy

[13] PISA. (2012). Field Trial Problem Solving Framework. (Online), http://www.oecd.org/pisa/pisaproducts/4696200 5.pd, diakses tanggal 26 Juni 2017.

[14] Safilu. (2010). Hakekat dan Stretegi Pembelajaran Biologi untuk Memberdayakan Keterampilan Berpikir Siswa. Jurnal Pendidikan Biologi, 2(1): 1-11.

[15] Wilujeng, Biyan Yesi. 2014. Pengembangan Perangkat Pembelajaran Strategi Belajar Mind Mapping Pada Model Pengajaran Langsung Standar Kompetensi Penataan Rambut (Styling) Di SMK. Jurnal Pendidikan Vokasi: Teori dan Praktek ISSN : 2302-285X 31 Agustus 2014. Vol.2 No.2.

[16] Buzan, Tony. (2010). Buku Pintar Mind Mapping. Jakarta: Gramedia Pustaka Utama.

[17] Jackson, Eddie B. (2016). Concept Mapping: Developing Critical Thinking through Mind Mapping. Online: https://www.usma.edu/cfe/Literature/EJackson 16.pdf. 17 September 2017.

[18] Irvine L. (1995). Can concept mapping be used to promote meaningful learning in nursing education? Journal of Advanced Nursing 21, 11751179.

[19] Jarvis P. (1992). Paradoxes of learning. San Francisco: Jossey-Bass.

[20] ABET. (2011). Criteria for accrediting engineering program. Retrieved from

http://www.abet.org/uploadedFiles/Accreditation/Accreditation_Proces s/Ac creditation_Documents/Current/eac-criteria-2012-2013.pdf

[21] Wheeldon, J., \& Faubert, J. (2009). Framing experience: Concept maps, mind maps, and data collection in qualitative research. International Journal of Qualitative Methods, 8(3), 68-83.

[22] Priantini, dan Marhaeni. 2013. Pengaruh Metode Mind Mapping Terhadap Keterampilan Berpikir Kreatif Dan Prestasi Belajar IPS. eJournal Program Pascasarjana Universitas Pendidikan Ganesha Volume 3 Tahun 2013 1-10.

[23] Pujiasih, et al. (2011). Perbedaan Model Pembelajaran DI Melalui Meode Mind Mapping dan Meode Konvensional Terhadap Kemampuan Berfikir Kreatif dan Prestasi Belajar Fisika Siswa SMP Wahid Hasyim. Malang: Universitas Kanjuruhan.

[24] Dixon, A Raymond. 2014. Cognitive Mapping Techniques: Implications for Research in Engineering and Technology Education. Journal of Technology Education Vol. 25 No. 2, Spring 2014. 